\title{
The Nordic textile commitment
}

A proposal of a common quality requirement system for textile collection, sorting, reuse and recycling

\section{reuse and recycling} commitment

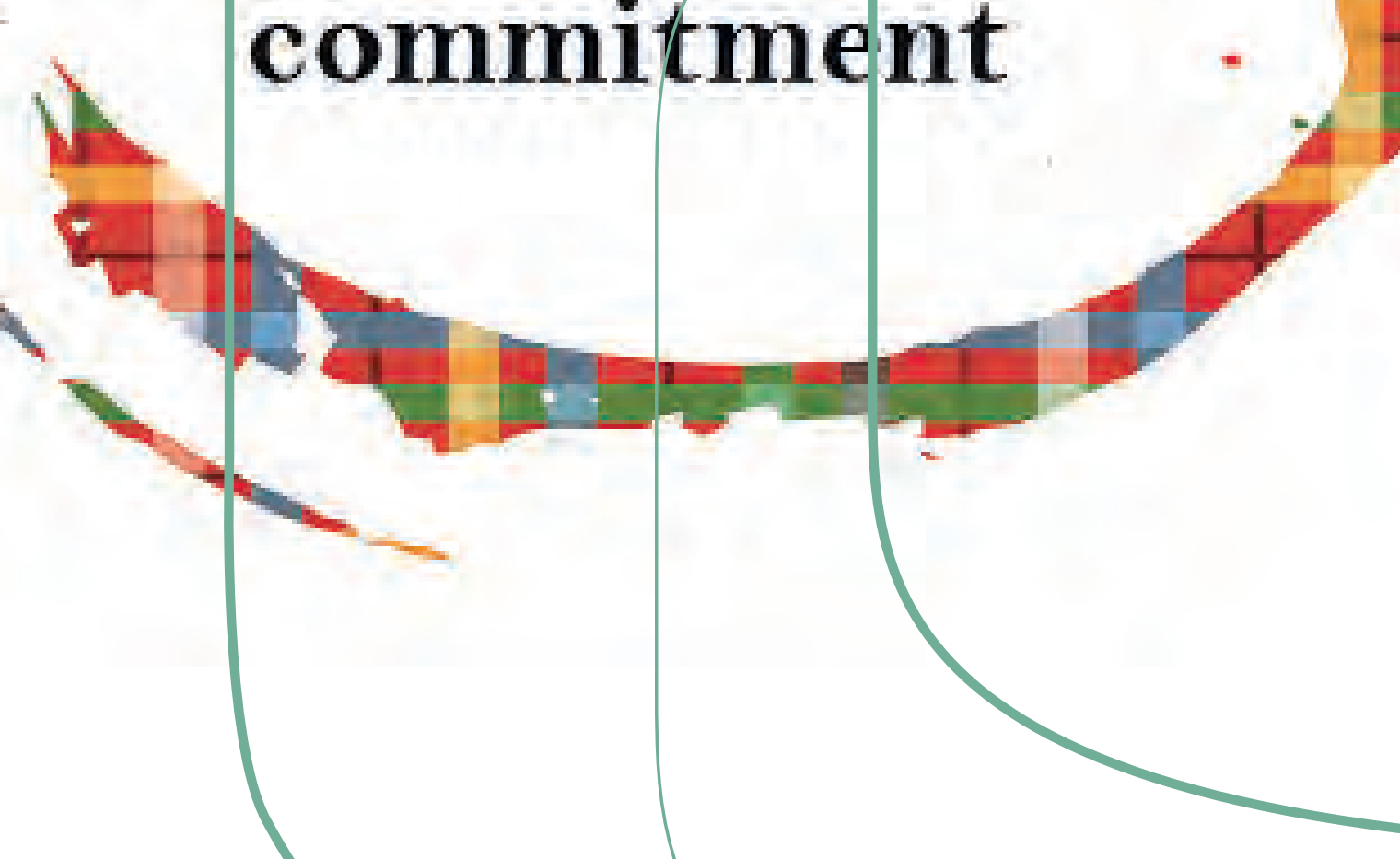



2 norden 



\section{The Nordic textile commitment}

A proposal of a common quality requirement system for textile collection, sorting, reuse and recycling

David Palm, Maria Elander, David Watson, Nikola Kiørboe, Synnøve Rubach, Ole-Jørgen Hanssen and Stefán Gíslason 
The Nordic textile commitment

A proposal of a common quality requirement sys-tem for textile collection, sorting, reuse and recycling

David Palm, Maria Elander, David Watson, Nikola Kiørboe, Synnøve Rubach, Ole-Jørgen Hanssen and Stefán Gíslason

ISBN 978-92-893-3965-0 (PRINT)

ISBN 978-92-893-3967-4 (PDF)

ISBN 978-92-893-3966-7 (EPUB)

http://dx.doi.org/10.6027/ANP2015-512

TemaNord 2015:512

ISSN 0908-6692

(C) Nordic Council of Ministers 2014

Layout: Hanne Lebech

Cover photo: Signelements

Print: Rosendahls-Schultz Grafisk

Printed in Denmark

This publication has been published with financial support by the Nordic Council of Ministers. However, the contents of this publication do not necessarily reflect the views, policies or recommendations of the Nordic Council of Ministers

\section{www.norden.org/en/publications}

Nordic co-operation

Nordic co-operation is one of the world's most extensive forms of regional collaboration, involving Denmark, Finland, Iceland, Norway, Sweden, and the Faroe Islands, Greenland, and Åland.

Nordic co-operation has firm traditions in politics, the economy, and culture. It plays an important role in European and international collaboration, and aims at creating a strong Nordic community in a strong Europe.

Nordic co-operation seeks to safeguard Nordic and regional interests and principles in the global community. Common Nordic values help the region solidify its position as one of the world's most innovative and competitive.

\section{Nordic Council of Ministers}

Ved Stranden 18

DK-1061 Copenhagen K

Phone (+45) 33960200

\section{www.norden.org}




\section{Content}

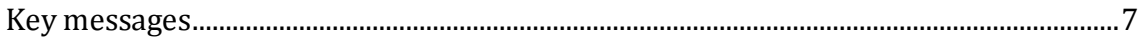

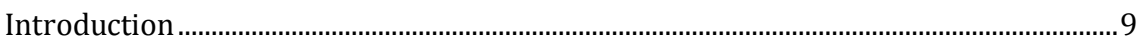

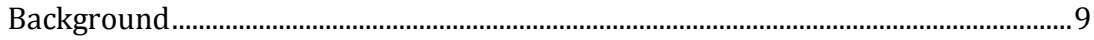

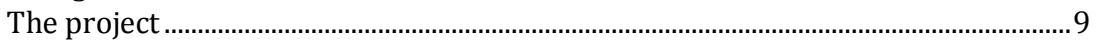

Summary of the reports........................................................................................... 10

Voluntary commitment................................................................................................. 15

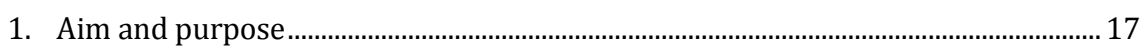

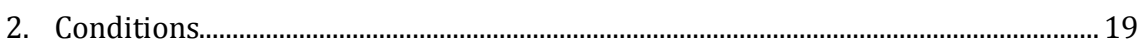

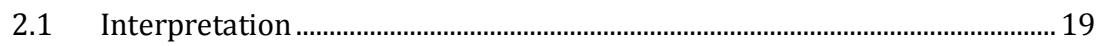

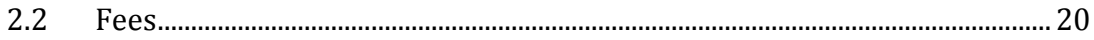

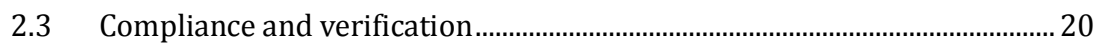

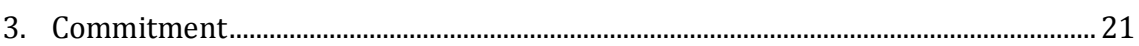

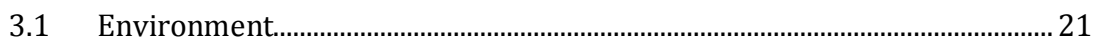

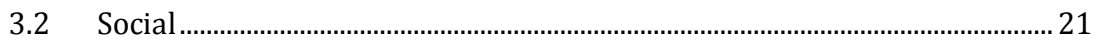

3.3 Communication and promotion .................................................................... 22

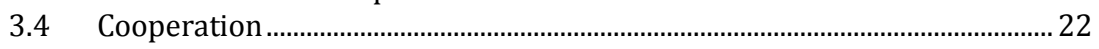

3.5 Compliance with national and international laws.......................................... 22

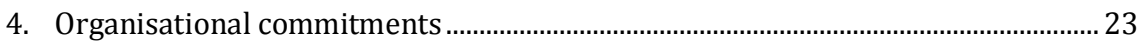

4.1 Collectors, sorters, recyclers and reuse traders.......................................... 23

4.2 Importers and producers of textile .................................................................... 23

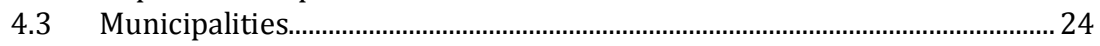

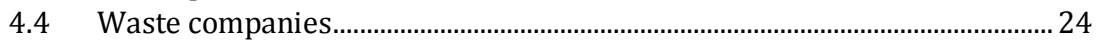

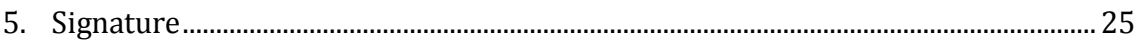

Code of conduct for management of used textiles ........................................................... 27

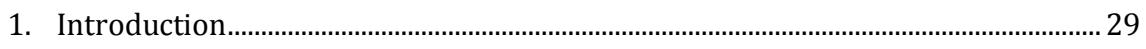

2. Information, transparency and reporting.............................................................. 31

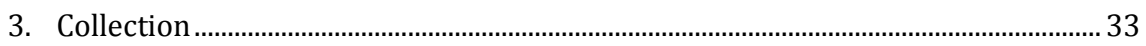

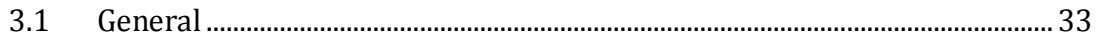

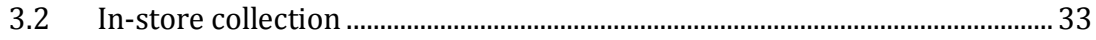

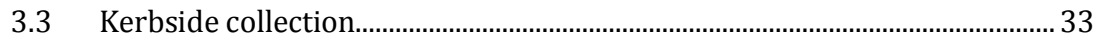

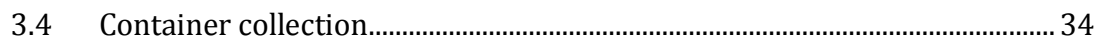

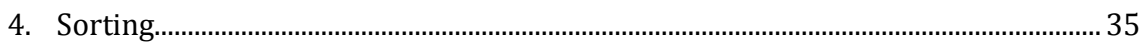

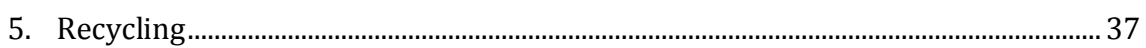

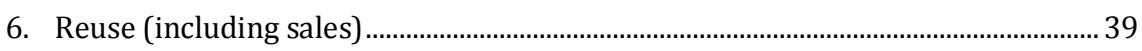

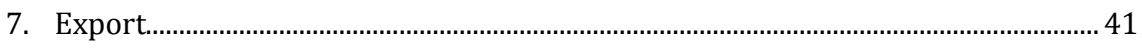

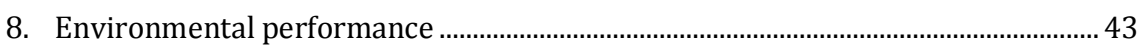

8.1 Overall environmental performance ............................................................. 43

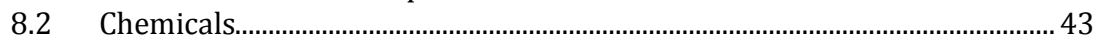




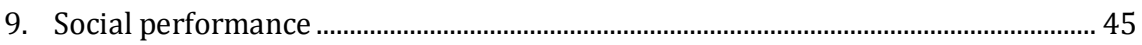

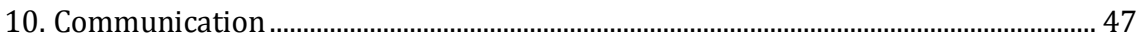

Certification and system operation .......................................................................... 49

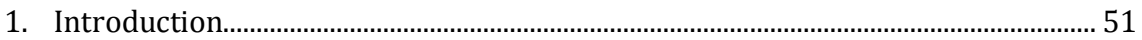

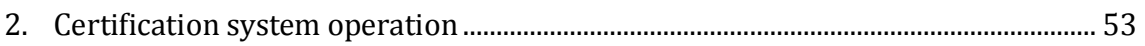

2.1 Role and function of certification operator....................................................... 53

2.2 Role and function of certification committee.................................................. 54

2.3 Revision of the certification system and criteria ............................................ 54

3. Certification organisations................................................................................... 55

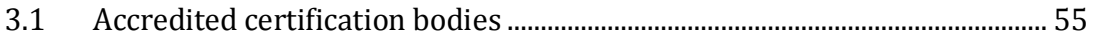

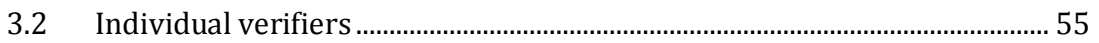

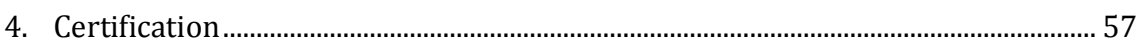

4.1 The certification process ................................................................................. 57

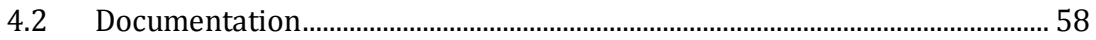

4.3 Validity of certification....................................................................................... 58

4.4 Irregularity reports and sample checks.......................................................... 58

5. Logotypes ............................................................................................................ 59

5.1 The collector, sorter, recycler and reuse trader logotypes .......................... 59

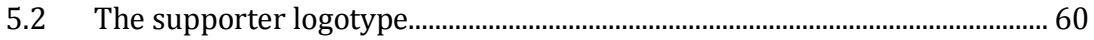

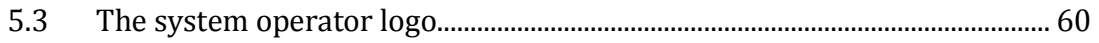

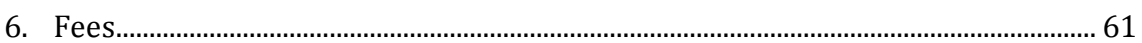

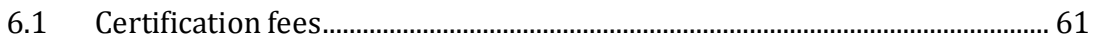

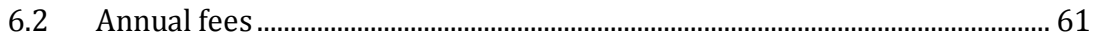

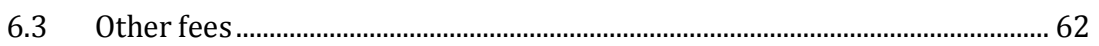

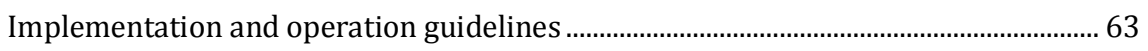

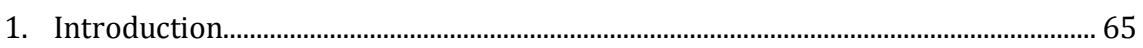

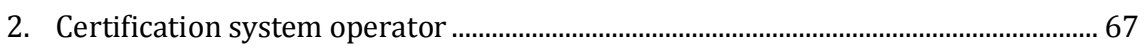

2.1 Models for organisation of the certification system operator

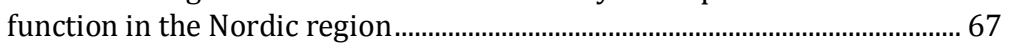

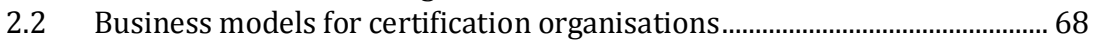

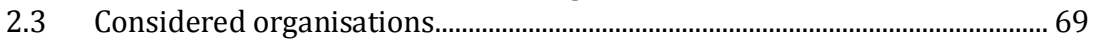

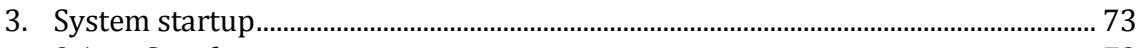

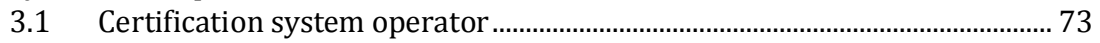

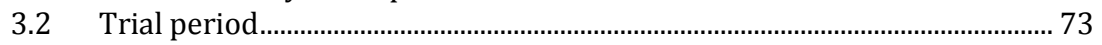

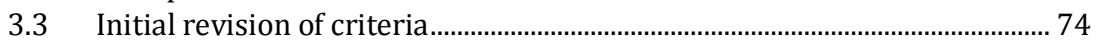

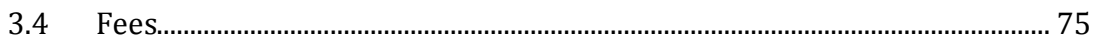

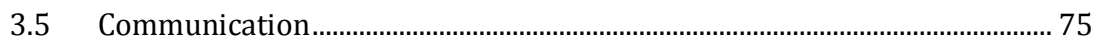

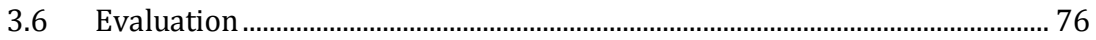

4. Guidelines for Nordic textile commitment.......................................................... 77

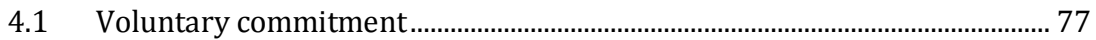

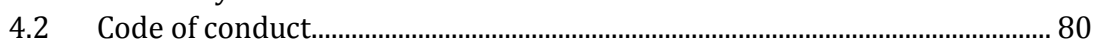

4.3 Certification and system operation.................................................................. 84

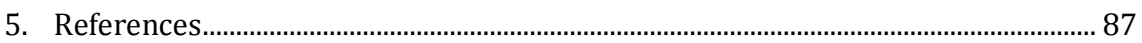

Sammanfattning av rapporterna ...................................................................................... 89

Uppförandekod för hantering av begagnade textilier .............................................. 90

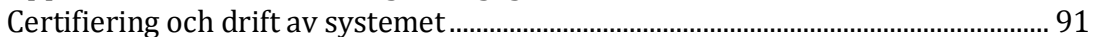

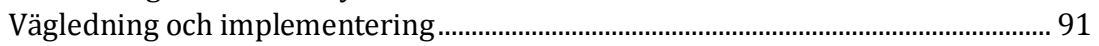

Actors supporting the Voluntary Commitment .............................................................. 93 


\section{Key messages}

The Nordic textile reuse and recycling commitment aims to engage stakeholders in committing to common goals of reducing the environmental impact from textile consumption and increasing the competitiveness of the Nordic region. It provides a third party certified system for legitimate sustainable collection, sorting, reuse and recycling of textiles by the participating actors.

The aim of the project as stated in the tender from the Nordic waste group:

[...] to develop a common quality requirement system for textile collection, reuse and recycling companies based on a voluntary commitment system organized by a Nordic body or by national bodies [...].

The Commitment has been developed in close relation to textile industry, collectors, municipalities and waste companies to ensure reasonable criteria. These should be possible both to achieve and to control while still setting clear ambitions for the management of used textiles and textile waste.

The key goals of the commitment are:

- Strive towards a ten year goal of at least $50 \%$ of collected textiles are reused (either in Nordic countries or abroad) and $90 \%$ of the total is reused or where reuse not possible, recycled. Aim towards closed loop recycling rather than downcycling.

- Ensure that all actors comply with third party verified social code of conducts.

The report covers the main principles of a voluntary commitment that together with a Code of Conduct document covers details for collectors, sorters, reuse traders, recyclers, municipalities, waste companies and producers/importers of textile. A certification and system operation document covers criteria for the operation and development of the system including fees and audits. 
This voluntary commitment is not a voluntary system for producer responsibility and does not replace other measures for a more sustainable management of textiles in the Nordic countries. 


\section{Introduction}

\section{Background}

This is the second report in the project The Nordic textile reuse and recycling commitment. The first report is published titled Towards a new Nordic textile commitment, TemaNord, ISSN 0908-6692; 2014:540 giving background information to the project.

The project is one of three projects to increase the reuse and recycling of textiles in the Nordic region financed by the Nordic Council of Ministers and proposed by the Nordic Waste group. All three projects are part of the Nordic Prime Minister's initiative, The Nordic Region leading in green growth, which identifies eight priorities aimed at increasing green growth in the region. The other textile projects are $A$ Nordic strategy for collection, sorting, reuse and recycling of textiles and An extended producer responsibility (EPR) system and new business models to increase reuse and recycling of textiles in the Nordic region.

The aim of the project as stated in the tender from the Nordic waste group:

[...] to develop a common quality requirement system for textile collection, reuse and recycling companies based on a voluntary commitment system organized by a Nordic body or by national bodies [...].

(Tender published by the Nordic waste group, April 2013).

\section{The project}

The project is carried out by a consortium with IVL Swedish Environmental Research Institute (Sweden), Copenhagen Resource Institute (Denmark), Ostfold Research (Norway) and Environice (Iceland). David Palm at IVL acts as project manager.

The work is performed in close connection with the Nordic waste group and Coordinator Yvonne Augustsson and also has a reference group connected to the project to ensure the outcome of the project. Related to this project are also two Nordic workshops organized by the Sustainable Fashion Academy on behalf of the Nordic Council of Ministers. 
The project was performed June 2013 to December 2014.

The reference group in the project were:

- Arnt-Willy Hjelle, Fretex, Norway.

- Cecilia Brännsten, H\&M, Sweden.

- Elisabeth Dahlin, Swedish Red Cross, Sweden.

- Emma Enebog, Myrorna, Sweden.

- Erik Hove, Danish Red Cross, Denmark.

- Frode Syversen, Mepex, Norway.

- Helene Personne, City of Stockholm, Sweden.

- Inge Werther, Dakofa, Denmark.

- Jesper Rønn-Simonsen, Kirkens Korshaer, Denmark.

- Jon Nilsson-Djerf, Waste Management Sweden, Sweden.

- Kaj Pihl, UFF Denmark, Denmark.

- Karin Sundin, City of Stockholm, Sweden.

- Klaus Rosinski, HumanBridge, Sweden.

- Minja Huopalainen, UFF Finland, Finland.

- Sara Winroth, Lindex, Sweden.

- Stina Moberg, City of Gothenburg, Sweden.

Some organisations have been represented also by other colleagues for part of the work.

\section{Summary of the reports}

This report provides the complete documentation of the developed Voluntary Commitment for increased reuse and recycling of textiles in the Nordic region. It includes a document describing a Voluntary Commitment and four supporting documents.

The documents are:

- Voluntary Commitment.

- Code of Conduct for management of used textiles.

- Certification and System operation.

- Guidelines and implementation.

- List of actors supporting the Voluntary Commitment.

The report is part of the Nordic Prime Minister's overall green growth initiative: "The Nordic Region - leading in green growth" - read more in 
the web magazine "Green Growth the Nordic Way" at nordicway.org or at norden.org/greengrowth

\section{Voluntary Commitment}

This document describes a general framework for a voluntary commitment between actors in the textile value chain and authorities in the Nordic countries. It includes commitments related to environment, social performance, communication, cooperation and compliance with laws on a general level as well as specific commitments for actors in the different stages of the reuse and recycling of textiles. Textiles included are clothing and home textiles.

The voluntary commitment consists of negiotiated goals for the industry as well as specific commitments for the different actors in the textile value chain. The commitment is not a voluntary system for producer responsibility and does not replace other measures for a more sustainable management of textiles in the Nordic countries.

The aim of the voluntary commitment is to engage stakeholders in commiting to common goals of reducing the environmental impact from textile consumption and increasing the competitiveness of the Nordic region. It provides a third party certified system for legitimate sustainable collection, sorting, reuse and recycling of textiles by the participating actors. Signatories are responsible for criteria within their domain of operation.

The goals of the commitment are to:

- Enable legitimate actors to collect, sort, reuse and recycle textiles in cooperation with producers, importers and authorities.

- Eliminate the illegal collection, export and trading of post-consumer textiles.

- Increase transparency on the fate of collected textiles and the purpose of the collection and increase public confidence in collecting organisations.

- Within ten years double the share of post-consumer textiles that are collected separately across the Nordic region compared to 2012 .

- Strive towards a ten year goal of at least $50 \%$ of collected textiles are reused (either in Nordic countries or abroad) and $90 \%$ of the total is reused or where reuse not possible, recycled. Aim towards closed loop recycling rather than downcycling.

- Ensure that all actors comply with third party verified social code of conducts. 


\section{Code of conduct for management of used textiles}

This document describes specific criteria related to the collection, sorting, reuse and recycling of used textiles. It is aimed at any organisation performing collection, sorting, reuse and recycling of used textiles, regardless of charitable status or not.

Criteria are given for collection in general and specifically for in store collection, kerbside collection and container collection. Criteria are also given for sorting, recycling, reuse and sales of reused textiles and export of used textiles as well as environmental performance, transparency and reporting. Criteria are divided into may and shall, where may are aspirational criteria and shall should be fulfilled and documented.

For actors claiming status as socially benefitial actors a list of ten criteria of which six must be fulfilled is provided. This enables "charities" in a broad definition to show consumers that they are providing an additional good beyond sound environmental management of textiles while still allowing for commercial actors to be part of the certification system.

\section{Certification and system operation}

This document describes all practicalities of the certification system around the voluntary commitment and code of conduct. It provides information on the system operation, certification organisations, the certification process and future development of the certification system.

The role of the certification operator is described together with a supporting certification committee. The certification operator is the organisation running the certification system in all practical aspects with appointing accredited verifiers, development of the system, information and maintaining registers of certified actors and fees. The certification operator does not perform certification audits, but approves organisations and individuals that do, based on predefined criteria. The certification committee consists of representatives for the various stakeholders affected by the system and aids the certification operator in the development of the system. It ensures that the system is able to adapt to changing conditions and has a continued relevance for the reuse and recycling of textiles.

The document also describes the certification process with required documentation, validity periods and checks and balances for certification. Certification fees for different actors and the conditions for fees are described. Finally preliminary logotypes and conditions for use of logotypes are given. 


\section{Guidelines and implementation}

The proposed system requires trials where suggested criteria can be tested to find any loopholes or other issues that needs to be resolved before a full implementation of the system. This document gives guidance for a test and start up of the proposed system. It provides a basic structure for the trial period and subsequent revisions of criteria.

It was not during the course of the project possible to find a certification operator ready to take ownership of the proposed system. A brief description of important factors for a certification operator and the considered organisations is also given here for future work on locating and appointing an operator of the system.

The development of the voluntary commitment has included negotiations of criteria to find a level where the management of used textiles is moved towards improved sustainability while still being possible to achieve. The final wording in the Voluntary Commitment, Code of Conduct and Certification and system operation documents have been carefully chosen and may be difficult for actors not involved in the development process to understand. This document therefore provides guidelines for all documents where more elaborated descriptions of several of the criteria are given. These guidelines are based on questions given during the development process.

\section{List of actors supporting the Voluntary Commitment}

The final document is a list of actors that actively have chosen to show their support for future development and implementation of the Voluntary Commitment and Certification system. The list include actors reaching from producers and municipalities to charity and commercial collectors from all over the Nordic region. 

Voluntary commitment 



\section{Aim and purpose}

The aim of the voluntary commitment is to engage stakeholders in commiting to common goals of reducing the environmental impact from textile consumption and increasing the competitiveness of the Nordic region. It provides a third party certified system for legitimate sustainable collection, sorting, reuse and recycling of textiles by the participating actors. Signatories are responsible for criteria within their domain of operation.

The goals of the commitment are to:

- Enable legitimate actors to collect, sort, reuse and recycle textiles in cooperation with producers, importers and authorities.

- Eliminate the illegal collection, export and trading of post-consumer textiles.

- Increase transparency on the fate of collected textiles and the purpose of the collection and increase public confidence in collecting organisations.

- Within ten years double the share of post-consumer textiles that are collected separately across the Nordic region compared to 2012.

- Strive towards a ten year goal of at least $50 \%$ of collected textiles are reused (either in Nordic countries or abroad) and $90 \%$ of the total is reused or where reuse not possible, recycled. Aim towards closed loop recycling rather than downcycling.

- Ensure that all actors comply with third party verified social code of conducts. 



\section{Conditions}

The conditions for the voluntary commitment are specified in this chapter with clarifications on phrases in the commitment.

\subsection{Interpretation}

The commitment and related documents include a number of words and phrases that should be interpreted in a specific way. This chapter clarifies these words:

- Signatory is the organisations signing the commitment on behalf of the actors in the textile sector and environmental authorities.

- System operator is the organisation that operates the system on behalf of the signatory parties, and which is responsible for validation of requirements and the commitment and for payment of fees.

- Shall means that a signatory must comply with the requirement. All shall requirements should be verified in a certification.

- May means that a signatory should if possible comply with the requirement.

- Collectors are organisations involved in separate collection of used textiles.

- Sorters are organisations performing sorting of textiles whether for reuse, recycling or other. Sorters include both professional sorters and in-store sorters.

- Recyclers are organisations performing recycling of textiles ranging from low grade to high grade recycling. Recyclers do not include organisations solely performing energy recovery.

- Traders are organisations selling textiles for reuse, recycling or sorting. Traders include second hand shops and exporting organisations.

- Importers are organisations importing new textile into the Nordic market.

- Producers are organisations producing new textile for the Nordic market. 
- Textile is defined as (re-)useable textile. It includes clothing and home textiles.

- Textile waste is defined as textile that is not reuseable.

- Separate collection of textile and textile waste means collection separated from materials with the risk of degrading the collected textile. It does not specifically mean separate collection of textile (reuseable textile) from textile waste (e.g. recyclable textile).

- Closed loop recycling is when textiles are recycled without considerable loss of quality in the recycled textile product.

- Downcycling is when textiles are recycled with significant loss of quality in the recycled product.

\subsection{Fees}

Fees for certification, management and development of the system shall be paid as specified in the document for system operation. Absence of payment is ground for exclusion from the system.

\subsection{Compliance and verification}

Failure to comply with the criteria stated in the voluntary commitment and related documents may lead to a warning and ultimately exclusion from the system. Minor deviations to the criteria during an audit shall be adjusted and reported according to the system operation document. Audits shall be performed every three years and unscheduled audits on all or parts of the criteria can be performed at any time. 


\section{Commitment}

This section specifies commitments valid for all signatories to the commitment.

\subsection{Environment}

All signatories shall with regards to textile and textile waste manage it according to the waste hierarchy as specified in EU Waste Framework Directive 2008/98/EC. In addition, closed loop recycling shall be prioritized before low grade recycling or "downcycling".

Figur 1. Waste hierarchy

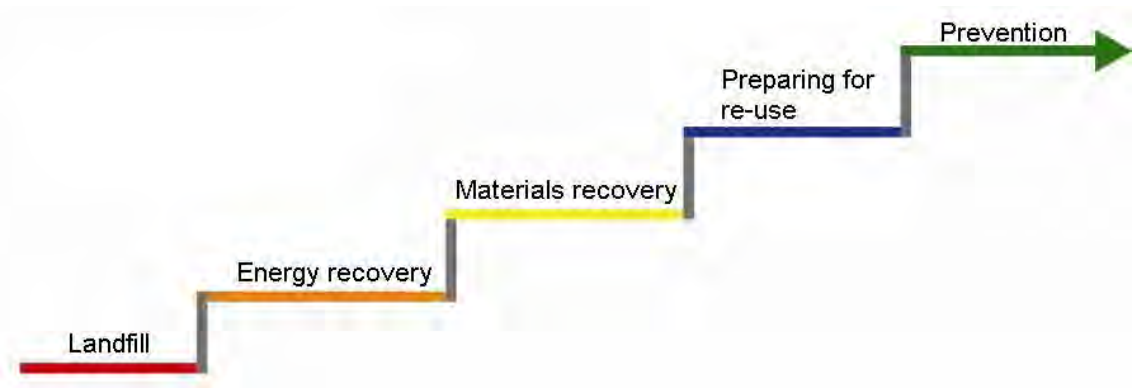

\subsection{Social}

Signatories and their partners needed to fullfill the critera of the voluntary commitment shall have a social code of conduct following the principles of the BSCI principles or similar. ${ }^{1}$

${ }^{1}$ Business Social Compliance Initiative. 


\subsection{Communication and promotion}

Signatories shall communicate the commitment to their staff and customers to ensure awareness and make it the standard for collection, sorting, reuse and recycling of textiles in the Nordic region and beyond. Communication may be performed by:

- Website information.

- Store information.

- Via social media platforms.

\subsection{Cooperation}

Signatories shall prioritize cooperation with other signatories before other actors when possible.

\subsection{Compliance with national and international laws}

All signatories shall comply with local, regional, national and international laws and regulations. In the case of a conflict between the commitment and the law, the law has precedence and the system operator shall be informed of the deviation. 


\section{Organisational commitments}

This section describes commitments made by different actors in the textile value chain. These commitments are in addition to the commitments in section 4. Note that one organisation can have commitments under several headings if relevant to their operation. ${ }^{2}$

\subsection{Collectors, sorters, recyclers and reuse traders}

Signatories involved in the collection, sorting, reuse and recycling of textiles commit to following the Code of Conduct attached to this voluntary commitment. Their activities should strive towards the common goal of the commitment.

\subsection{Importers and producers of textile}

Signatories putting new textiles on the Nordic market may, when possible, only cooperate with signatories in this commitment with regards to collection, sorting, reuse and recycling of textiles.

They shall actively and transparently communicate the commitment for instance in stores, websites or via other communication channels as a legitimate way for consumers to discard used textiles. Information shall include a reference to additional information about the system, e.g. a link/tag to the system website.

They may cooperate directly with signatories and market the opportunity to support a specific collector of textiles. Importers and producers may perform collection, sorting, reuse and recycling in accordance with the code of conduct.

2 E.g. An organisation can be both an importer and a collector. 


\subsection{Municipalities}

Municipalities shall promote and/or cooperate with signatories performing collection, sorting, reuse and recycling of textiles as a legitimate way for consumers to discard used textiles.

Municipalities shall, where possible, prioritise signatories when giving permits for collection on public land. They shall also take action against illegal collection.

Municipalities shall promote separate collection of textile and textile waste. ${ }^{3}$

Municipalities may shape public procurements to match criteria in the commitment for managing of used textile and textile waste.

Municipalities may perform collection, sorting, reuse and recycling in accordance with the code of conduct.

\subsection{Waste companies}

Waste companies shall promote and/or cooperate with signatories performing collection, sorting, reuse and recycling of textiles as a legitimate way for consumers to discard used textiles.

Waste companies shall promote separate collection of textile and textile waste.

Waste companies may perform collection, sorting, reuse and recycling in accordance with the code of conduct.

${ }^{3}$ Separate collection of textile and textile waste means collection separated from materials with the risk of degrading the collected textile. It does not specifi-cally mean separate collection of textile from textile waste. 


\section{Signature}

By placing my signature on this document I hereby show my organisations intent to commit to the criteria stated here and to actively participate in the Nordic Reuse and recycling commitment.

Place

Date

Signature

Name and organisation
Place

Date
Signature

Name and organisation 

Code of conduct for management of used textiles 



\section{Introduction}

This code of conduct is part of a voluntary commitment signed by actors in the textile value chain. It provides rules and guidelines for securing a sustainable and responsible collection, sorting, reuse and recycling of used textiles.

It is aimed at any organisation performing collection, sorting, reuse and recycling of used textiles.

All criteria that are checked in an audit are marked with (Cx.x) to allow for a clear connection between an audit result and the criteria in the code of conduct. 



\section{Information, transparency and reporting}

All statements in the code of conduct stated as "shall" shall be verifiable during certification or recertification. (C2.1)

Traceability of textiles shall be possible up to the point of end users being either private customers, recycled products or final disposal. (C2.2)

Signatories are responsible for gathering all downstream information. If cooperation is made with a downstream signatory, the combined activities shall fulfil the criteria. (C2.3)

Documentation shall include receipts of all transfer of textiles to and from signatories and sorters, resellers or recyclers. Sorters, resellers and recyclers shall be able to verify the fate of received textiles (overall or specific to signatory) either directly with receipts or via third party certification. (C2.4)

All collected textiles shall be documented with weight or volume and source of origin. (C2.5)

Additional information on reporting requirements are found in the Certification and system operation document. 



\section{Collection}

It should be made clear to the person handing used textiles to collection actors where the textiles are going, what the purpose of the collection is, who is performing the collection and how to find more information about the certification system. (C3.1)

\subsection{General}

Collectors shall not knowingly accept textiles that originate from illegal collection or textiles with uncertain origin. (C3.2)

Collectors shall accept all other textiles that are clean and non hazardous. This includes torn, worn-out and incomplete textiles (e.g. single socks). This should be made clear to the consumer. (C3.3)

\subsection{In-store collection}

There shall be clear and correct information about the collection including name and contact information to the collector, reference to the system and the main purpose (see section 9 for details on social performance) of the textile collection. (C3.4)

\subsection{Kerbside collection}

The collector shall specify which day collection will take place. (C3.5)

There shall be clear and correct information about the collection including name and contact information to the collector, reference to the system and the main purpose (see section 9 for details on social performance) of the textile collection. (C3.6)

Information on which products are accepted in the collection shall be clearly stated to the consumer. This must be in agreement with the requirements under section 3.1 of this Code of Conduct. (C3.7) 
If material is not collected, due to not being textile, being soiled or otherwise contaminated, written information shall be given to the consumer. (C3.8)

\subsection{Container collection}

Textile containers shall only be placed after having achieved a permit for doing so by the competent authority and/or land owner. (C3.9)

There shall be a clear and correct labelling of textile containers including name and contact information to the collector, reference to the system including logotype and the main purpose (see section 9 for details on social performance) of the textile collection. (C3.10)

Stickers or similar shall be placed on the lids of the bins stating which materials are accepted in the collection. This must be in agreement with the requirements under section 3.1 of this Code of Conduct. Information in several languages may be used when appropriate. (C3.11)

Container sites shall be well maintained and the immediate area around the container shall be kept free from waste or textiles. (C3.12)

The collector shall ensure that bins are emptied frequently and that they are clearly marked with contact details in the event of problems. (C3.13) 


\section{Sorting}

Sorters shall not accept textiles that originate from illegal collection or textiles with uncertain origin. (C4.1)

Sorters shall report sorting performance in percentage byweight or volume of received textiles whose next stage is in:

- Reuse. (C4.2)

- Recycling. (C4.3)

- Incineration with energy recovery. (C4.4)

- Landfill or incineration without energy recovery. (C4.5)

Sorting performance as described above shall be given for each specific supplier or as the residual of received material not included in sorting performance for a specific supplier. (C4.6) 



\section{Recycling}

Recyclers shall report the level of recycling in percentage weight or volume of received textiles and the distribution between categories of recycled products. (C5.1)

Recyclers shall report the fate of recycling residues. (C5.2) 



\section{Reuse (including sales)}

Sales of textiles by a certified actor may only be associated with the certification system if all reused textiles are included in the certification system. Sales of certified textiles together with new textiles are allowed if it is clear that new textiles are not collected within the certification system. See also section 3.1 and 3.2. (C6.1)

The percentage of sold (or donated) used textiles as a share of received used textiles together with the fate of unsold textiles shall be reported. Only the sold or donated (actually reused by a final user) textiles may be included as reused. (C6.2) 



\section{Export}

Collected used textiles shall only be sold to companies with the requested competence regarding handling of these material flows. (C7.1)

Equal rules as described in this code of conduct apply for export of textiles as for domestic sorting, reuse (sales) and recycling. Other existing third party certification ensuring compliance with the criteria of the certification may be used as documentation for international actors. (C7.2) 



\section{Environmental performance}

Collected textiles shall be treated according to the Waste hierarchy stated in the waste framework directive (2008/98/EC). (C8.1)

At least $50 \%$ of collected textiles shall be reused (annually) either by charity reuse, domestic sales or by export to an organization guaranteeing the level of reuse. (C8.2)

At least $90 \%$ of collected textiles shall either be reused or used as input for recycling (annually). The recycling should have a material efficiency of at least $60 \%$. Recycling of textiles not suitable for reuse shall be according to best available technique with priority given to closed loop recycling before low grade recycling. (C8.3)

Signatories comply with the criteria for environmental performance if they only reuse textiles and send the remaining textiles to another signatory that fulfils criteria C8.2 and C8.3. (C8.4)

Collected items that are not textiles should not be included in the calculation regardless of being waste or other products with the exception of shoes. If shoes are included, this should be clearly stated. (C8.5)

\subsection{Overall environmental performance}

All signatories shall in all stages of the textile life cycle actively work towards an efficient management of textiles. This includes transports, facilities and all other activites related to the collection, sales/reuse, sorting and recycling of textiles. (C8.6)

\subsection{Chemicals}

All signatories shall work towards the removal of used textiles known to contain hazardous or otherwise unwanted chemicals. (C8.7) 



\section{Social performance}

Actors within the code of conduct with a purpose of social benefit may use the expanded logotype including a text of "for social benefit". ${ }^{4}$ Since social benefit can include a wide range of activities, six of the critera listed below shall be fulfilled to include the social benefit text. ${ }^{5}$ Either criteria 1 or 2 must be fulfilled for all actors claiming social benefit.

A socially benefitial actor shall (for at least six of the following criteria): (C9.1)

1. Mainly reinvest profits in own or similar enterprises.

2. Be non-profit.

3. Have as main purpose to integrate people with significant difficulties getting employment and/or staying employed.

4. Create partnership for coworkers through ownership, contracts or in other documented ways (e.g. membership).

5. Be structurally independent from the public sector.

6. Be certified as having charity status. ${ }^{6}$

7. Mainly be operated by volunteers.

8. Have clear and transparent economic accounting.

9. Protect human equity and equal rights.

10. Have as main purpose to improve living conditions for humans living under particularly difficult conditions.

\footnotetext{
4 The reason for having a separate mark for social benefitial actors is due to the historic reasons for collecting used textile and the need to make it clear whether the donator of textile is supporting a socially beneficial actor or not.

5 The criteria are partly based on the criteria for social enterprise used by the Swedish Agency for Economic and Regional Growth (Tillväxtverket).

${ }^{6}$ Examples are being the holder of a "90-konto", being approved for tax deductions for charitable donations, etc.
} 



\section{Communication}

All communication about the certification and collection, reuse/sales, sorting and recycling of textiles not elsewhere addressed shall be clear and with reference to the certification system website. Use of logotypes is only allowed if in compliance with the conditions specified in the certification system operation document. (C10.1) 

Certification and system operation 



\section{Introduction}

This document provides information on the system operation, certification organisations, the certification process and future development of the certification system. 



\section{Certification system operation}

The certification system includes a certification system operator, a certification committee and the criteria of the certification. This section provides key descriptions of their roles and responsibilities.

\subsection{Role and function of certification operator}

The main role of the certification operator will be to take responsibilty for:

- Promote reuse and recycling of textiles.

- Promote the certification system.

- Certifying signatory organisations.

- Defining the necessary cost for operating the system and the size of the fees for certification.

- Inform relevant stakeholders about the rationale behind and benefits of textile recycling and reuse, and how the system functions.

- Register all signatories to the system and operate statistics for how much each member shall pay and how much they have paid.

- Develop statistics for collection, recycling and reuse of textiles for actors within the system.

- Retaining all records regarding the standard for a minimum number of years.

- Enforce sanctions for malpractice or illegal activities.

- Lead the future development of the system.

- Inform signatories and the general public on the development of the system and new certifications.

- Publicly display documentation from certification committee meetings.

- Investigate reported irregularities for certified actors. 


\subsection{Role and function of certification committee}

The certification system shall have a committee that assists the certification system operator in decisions regarding development of the system, approval of verifiers to the system, setting fees and general certification issues.

The certification committee shall be 8-10 members with at least:

- 2 producers or importers.

- 2 representatives from government.

- 2 collectors or sorters.

The committee members are appointed by the certification system operator together with representatives from the Nordic governments. Each category mentioned above may also be represented by branch organisations. A diversity of organisations and Nordic countries shall be aimed for when selecting committee members to ensure a broad representation.

\subsection{Revision of the certification system and criteria}

Revision of the certification criteria shall be done after 6 months of operation and then annually. The stated validity of certifications shall be unaffected by changes of certification criteria.

The current version of the criteria is 0.1 . 


\section{Certification organisations}

Certification can be done either by accredited certification bodies or by individual verifiers. There is no fee from the system associated with becoming an individual verifier.

\subsection{Accredited certification bodies}

Certification bodies can perform certification audits given that they are accredited by any of the Nordic Accreditation agencies (e.g. SWEDAC). A list of accredited certification bodies shall be available on the system website.

\subsection{Individual verifiers}

Individual verifiers can perform certification audits provided that they have been approved by the certification system operator.

General requirements on individual verifiers are:

- Independent in relation to certifiable organisations.

- General knowledge of the textile industry.

- Good knowledge on the the transparency and traceability of textiles.

- In-depth knowledge on the Voluntary commitment, code of conduct and certification system operation.

- Having performed at least 5 third party reviews of quality systems. ${ }^{7}$

- In-depth knowledge of the ISO 19011 Management systems auditing criteria.

Applications for becoming an individual verifier should be sent to the certification operator and will be reviewed by the certification committee. The first certification made by an individual verifier will be thoroughly checked by the certification operator and certification committee to ensure compli-

${ }^{7}$ E.g. ISO9001, ISO14001, Miljödiplom - Svensk Miljöbas. 
ance with the certification criteria. After approval, sample checks on future certifications may be carried out by the certification operator.

A list of approved verifiers shall be available on the certification system website. 


\section{Certification}

Certification can be made both to a legal entity and to an organisation consisting of several legal entities.

\subsection{The certification process}

A number of steps must be performed by the applicant before a certification of an organisation is made.

a) Fill in the application form for certification on the system website.

b) Contact either an accredicted certification body or an individual verifier to perform the certification audit.

c) Compile all needed documentation as described in the section documentation.

d) The certifier performs the audit, see checklist in appendix. ${ }^{8}$

e) Site visits at 1-10 sites are performed by the certifier. ${ }^{9}$

f) The certifier sends an audit report to the certification operator.

g) If approved, applicable fees are paid and a certificate is issued.

Note that the agreement between the accredited certification body or the individual verifier performing the certification audit and the organisation seeking certification does not involve the certification system operator. If the application for certification is not approved by the certification system operator, there are no applicable fees to the system.

\footnotetext{
${ }^{8}$ Not yet available.

${ }^{9}$ The number of site visits depend on the complexity of the operation, (if) previous certification results and other factors and can if found necessary by the auditer be expanded beyond 10 sites.
} 


\subsection{Documentation}

The fulfilment of all criteria shall be documented accordingly. All transactions where textile changes owner shall be properly documented and available to the auditor.

Performance of all downstream actors shall be documented and available to the auditor. ${ }^{10}$

In case of irregularities during the previous certification period, these together with corrections shall be documented and supplied to the auditer.

\subsection{Validity of certification}

A certificate is normally valid for 3 years.

If significant changes to the signatory operation are made during this period a supplementary certification shall be performed. If there is any uncertainty to whether a change constitutes a significant change, the certification system operator shall be notified.

For irregularities found during the certification period, see section 4.4.

\subsection{Irregularity reports and sample checks}

During the validity of a certification, sample checks of signatory operation may be performed. These include but are not limited to:

- Site visits.

- Random criteria checks.

- Deviation report requests.

Reports of irregularities found may be sent by anyone to the certification system operator at any time to be investigated.

If irregularities are found, a request to correct and explain the irregularity will be sent by the certification system operator. Failure to comply may lead to exclusion and withdrawal of the certification.

${ }^{10}$ Actors following the signatory in the value chain. E.g. a sorter contracted by a certified collector 


\section{Logotypes}

The commitment includes a number of logotypes. These may only be used under the following conditions after written permission from the system operator.

\subsection{The collector, sorter, recycler and reuse trader logotypes}

A logotype "Approved textile collection" with link/barcode to more information. This logotype can only be used by actors within the commitment performing collection, sortin, recycling or trading of used textiles.

For use of the additional text "for social benefit", see criteria for social performance in the Code of Conduct.

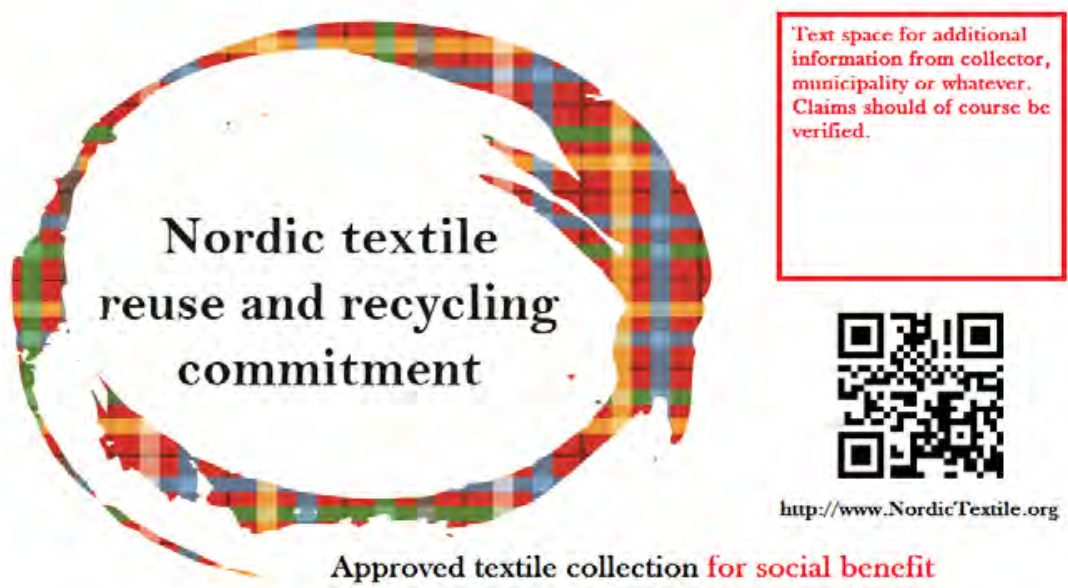




\subsection{The supporter logotype}

A logotype "Supporting approved textile collection" with link/barcode to more information. This logotype can only be used by actors within the commitment.

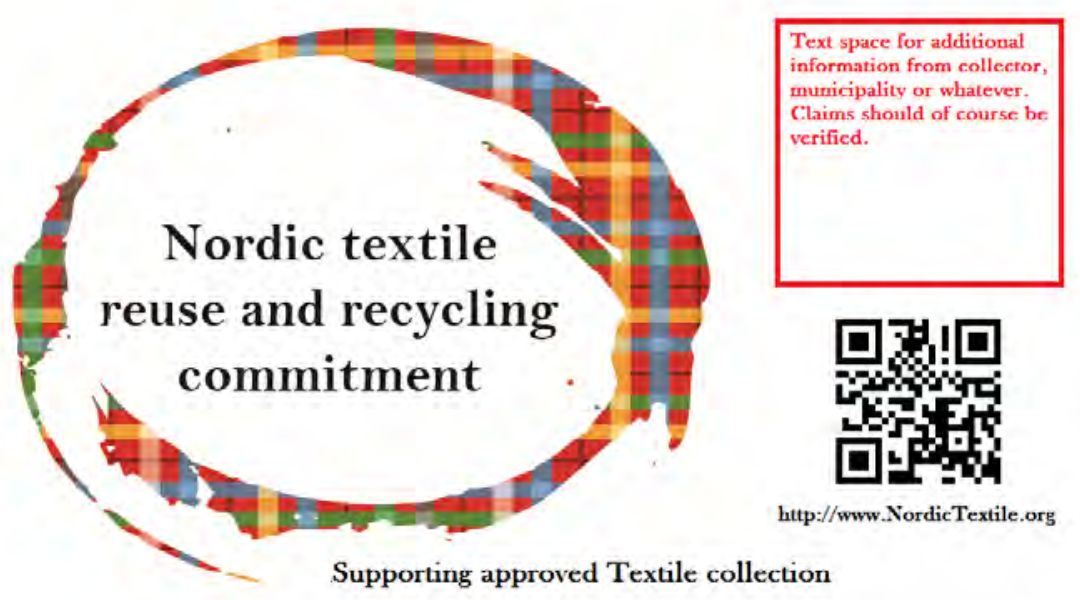

\subsection{The system operator logo}

This logotype can only be used by national governments and system operator(s).

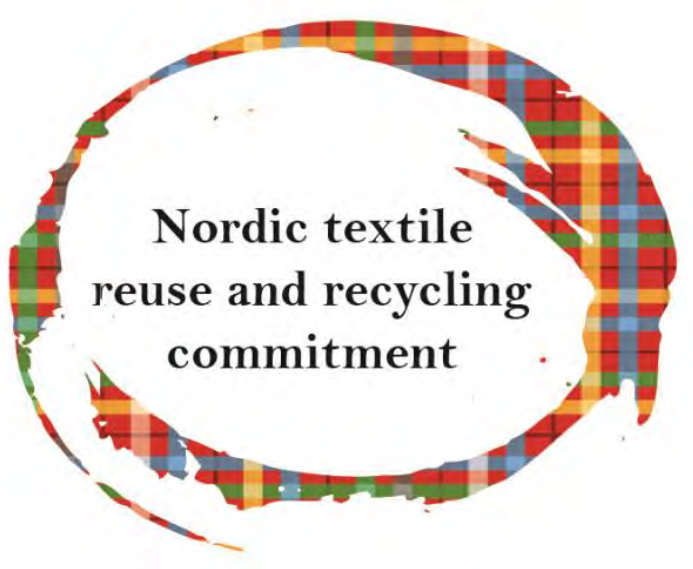




\section{Fees}

The certification system shall be non-profit and fees shall be adjusted to only compensate for the operational costs of the system. Fees paid to accredited certification bodies and individual verifiers for certification audits are not presented here and are set as individual agreements between them and the organisation applying for certification. The fees presented here are only very preliminary and are subject to change.

\subsection{Certification fees}

The certification entails a fee to the certification system in addition to the cost of the approved certifying body (which is agreed directly with the approved certifying body). The fee covers administration of the certificate during the validity period.

The certification fee is set by the certification system operator together with the certification committee.

A possible fee may be EUR $600+$ VAT.

\subsection{Annual fees}

A certified collector shall pay an annual fee to the certification system. The fee covers development, communication and general operation of the system. The annual fee is set by the certification system operator together with the certification committee. Failure to pay the annual fee will lead to exclusion and a withdrawal of the certification.

For collectors, sorters, reuse and recyclers the annual fee is diversified based on collected amounts of textile annually:

\begin{tabular}{lll}
\hline Collected amounts & Corresponding size & Possible annual fee \\
\hline$<=100$ tonnes & Small & EUR $100+$ VAT \\
$100>=1000$ tonnes & Medium & EUR $500+$ VAT \\
$1000>=10,000$ tonnes & Large & EUR $1,000+$ VAT \\
$>10,000$ tonnes & X-Large & EUR $2,500+$ VAT \\
\hline
\end{tabular}


For businesses supporting the certification system the annual fee is diversified on number of employees:

\begin{tabular}{lll}
\hline No. of employees & Corresponding size & Possible annual fee \\
\hline $1-10$ & Small & EUR $100+$ VAT \\
$11-250$ & Medium & EUR $500+$ VAT \\
$>250$ & Large & EUR $1,000+$ VAT \\
\hline
\end{tabular}

Municipalities supporting the certification are free from annual fees.

\subsection{Other fees}

The certification system operator may claim fees for reminders for payment and similar according to normal practice. 


\section{Implementation and operation guidelines}





\section{Introduction}

This document gives information related to the implementation and operation of the certification system. A certification body has not been found during the course of the project but criteria for a suitable body and some of the investigated options are described in this document.

The certification system has been developed in close relation to textile industry, collectors, municipalities and waste companies to ensure reasonable criteria that are possible both to achieve and to control while still setting clear ambitions for the collection, reuse and recycling of used textiles and textile waste. It has however not within the project been possible to capture all possible effects and there is always the possibility of unintended effects when introducing a new system. The proposed startup phase of the system is therefore described here suggesting an initial trial period where criteria are tested both to find any loopholes and unforeseen difficulties.

The voluntary commitment, code of conduct and certification system documents can be difficult to understand for actors not having been involved in the development of the system. The final section of this document provide questions and answers that give some explanation to why the criteria are written in a certain way and why some criteria are needed and some are not needed. 



\section{Certification system operator}

This section describes requirements on a certification system operator and possible options for organising the system. It also provides some information on the possible certification operators considered. As written in the voluntary commitment overarching the system, the aim of the voluntary commitment is to engage stakeholders in committing to common goals of reducing the environmental impact from textile consumption and increasing the competitiveness of the Nordic region. It provides a third party certified system for legitimate sustainable collection, sorting, reuse and recycling of textiles by the participating actors.

\subsection{Models for organisation of the certification system operator function in the Nordic region}

Based on discussions in the Nordic textile project phase I, the intention is to establish a Certifying System with a Certifying Organisation through the project phase II. There are three principally different models for establishment of such an organisation in the Nordic region:

1. One common Certifying Organsation for the whole Nordic region.

2. National independent Certifying Organisations similar to the system with Innsamlingskontroll (Norway and Sweden) which control how organisations who collect money to specific projects or activities allocate the income between administration and different projects.

3. National Certifying Organisations within a common Nordic structure ("Holding company"). This is much like how for instance the Nordic Swan labelling system and the Forest Stewardship Council (FSC) system for forest management function today.

In all models it is possible to establish a system with basis in existing systems and organisations for certification, labelling and control. If there are relevant organisations available, this will probably be more resource efficient than to establish a completely new system for only this task. Both model II based in integration with organisations similar to Innsamlingskontrollen nationally or model III based in integration with an exist- 
ing Nordic system is probably better alternatives than to start from scratch, if a relevant organisation is available. A system based in national institutions like Innsamlingskontrollen with a new Nordic organisation coordinating this part of the work could also be a relevant model.

\subsection{Business models for certification organisations}

Two different strategies can be chosen for further development of Certification organisations for reuse and recycling of used textiles and textile waste in the Nordic region:

1. Engage existing organisations that already are involved in relevant activities, e.g. Innsamlingskontrollen or the Nordic Swan.

a. There are few organisations at a Nordic level which today have the function as Certifying Organisation in waste collection and management.

b. There are national organisations which are dedicated to the role as Certification systems related to other relevant areas. These could be relevant as Certifying Organisations also for used clothes and textile on national levels, e.g. Innsamlingskontrollen in Norway and Sweden.

c. There are Nordic organisations which have their focus on other environmental programmes, like the Nordic Swan organisations, that might be interested in broadening their activities.

2. Establish new organisation(s) which can take the role of being Certifying Organisation nationally or on a Nordic level.

a. The textile industry in the Nordic countries could establish a common Nordic company or national companies which take the role as Certifying Body for collection and treatment of used clothes and textile.

b. The textile industry, textile collectors and other relevant stakeholders could organise a joint Nordic company or national companies to take the role as Certifying Organisation.

For both models, new organisations could be established either on a Nordic level, on national levels or as a combination like the Nordic Swan and FSC system. One alternative model is to establish an organisation owned by the relevant stakeholders themselves or in combination with government, which is the case for many other areas related to waste management or reuse of products, eg food banks, packaging waste, 
WEEE waste etc. The Food bank in Norway is a good example, which is owned by four charity organisations, food and retail companies (Hanssen et al. 2014 in prep). This is also the case today e.g. with Innsamlingskontrollen, which is owned by charity organisations in Norway (Innsamlingskontrollen, 2014) and by charity organisations and the business organisations in Sweden (Svensk Insamlingskontroll, 2014).

\subsection{Considered organisations}

A number of solutions for certification system operator have been considered, which are described below. Criteria for evaluating the suitability of different options have been likely cost for certification operation, flexibility for future system changes, possible European or global expansion and above all legitimacy and trustworthiness perceived by the industry stakeholders and the general public. The evaluation has been made by where possible comparing costs of current services, the perception of flexibility from users of current services and current geographical operation. It builds on both the authors experience of the evaluated actors, dialogue with the reference group connected to the project and publicly available information.

\subsubsection{The Nordic Ecolabel integrated}

The Nordic Ecolabel is a type 1 environmental labelling created in 1989 operating in all Nordic countries. It could include the criteria in the Nordic textile commitment and give the actors involved the ecolabel for the service of reuse and recycling of textiles and textile waste. Informal contact has been made during the project to investigate the possibilities of ownership of the commitment.

The Nordic ecolabel is highly regarded and scores high on legitimacy and trustworthiness. However there are som scepsis among the stakeholders that the operational cost and thereby fees would be high. ${ }^{11}$ There is also some doubt on the possible flexibility needed in such a rapidly changing area of operation and that choosing a Nordic label might cause issues with expansion outside the Nordic region. The Eco-

\footnotetext{
${ }^{11}$ As a rough comparison, the fee for the Nordic ecolabel on textiles is 20 times higher than the fee to Svensk Insamlingskontroll.
} 
label organisation has previously not been involved in similar activities with certifying collection systems and treatment systems.

More information on the Nordic Ecolabel is available at http://www. nordic-ecolabel.org/

\subsubsection{The Nordic Ecolabel separate}

Using the organisation of the Nordic Ecolabel but keeping the certification system separate from the label is substantially different than integrating the criteria into the complete Ecolabelling system. This would enable having the credibility of the Nordic Ecolabel but with a higher degree of freedom for development and operation of the system. The issue of cost and limitation to the Nordic region will however remain.

\subsubsection{Nordic innovation}

Nordic innovation is a Nordic institution working to promote crossborder trade and innovation. Nordic innovation is less known than the Nordic Ecolabel but may be more flexible in its organisation from being a smaller and newer actor with a clear mission to create value through cross-border co-operation. It is not clear whether Nordic innovation could take on a role as a certification system operator and what the associated costs might be and this needs to be investigated further. It could possibly be a part of Nordtest, a subsidiary of Nordic Innovation.

More information on Nordic Innovation is available at http://www. nordicinnovation.org/.

\subsubsection{Independent non-profit company}

An independent non-profit company can be created to act as a certification system operator. A similar construction was created in July 2014 for the International EPD-system (Type III Environmental declarations) which is now run as a subsidiary to IVL Swedish Environmental Research Institute. 12

This option enables a high level of flexibility in the future development of the certification system, comparably low operational costs and the possibility to expand beyond the Nordic countries. It however re-

12 http://environdec.com/en/The-International-EPD-System/Organisation/\#.U7_B9LHssX8 
quires careful consideration to ensure that the system will be run by an organisation that have or will achieve the trust and credibility needed to manage the system.

\subsubsection{Joint venture textile industry and collectors}

The certification system operator can be a joint venture between the textile industry and collectors of used textile. This would ensure involvement of key stakeholders and likely keep costs to a minimum. It would enable expansion outside of the Nordic countries and be flexible in terms of future development of the system. This solution however might give less control and insight for the Nordic governments and might not have the legitimacy of the other options. 



\section{System startup}

A new system always runs the risk of having unintended consequenses. These need to be managed from the start to ensure that the system is consistent and trustworthy. To include a shorter trial period in the system startup phase, proposedly managed by an interim certification organisation, will enable the smooth introduction and give the possibility to adjust the system. In the trial period criteria and processes can be tested in a live situation.

A number of details need to be covered by the board of the interim certification organisation during the implementation and start up of the certification system. These will likely change over time and will ultimately be decided by the certification system operator in cooperation with the certification committee (see certification and system operation). This section aims to provide a starting point for that work.

\subsection{Certification system operator}

A first step in establishment of a certification system is to create or involve an organisation to become the certification system operator. Criteria and suitable options for certification system operators are described in the previous section. An interim organisation with a board should have the mission to create a certification system operator organisation. In parallell, an interim certification committee with representatives from relevant external stakeholders, which should be created to give input on development of the system as described in the certification and system operation document.

\subsection{Trial period}

It is proposed to define a trial period of twelve months where a number of certification processes with actors supporting the development of the system. There should be a systematic evaluation of the trials at three, six and twelve months to enable for adaptation during the trial period, organised in close cooperation with the certification committee. The trials 
enable testing of the certification criteria and the certification processes. It can provide input to which criteria will be difficult to document or control in the certification audit, as well as provide a more detailed description to future applicants on how to prepare for the certification process and necessary costs to fulfil the certification process. A comprehensive checklist for certification should be developed covering all criteria. In addition, guidelines for how necessary documentation to fulfil the criteria should be prepared and be further developed throughout the trial period.

The trial period should include:

- Actors in all categories aiming for certification to ensure that documentation supporting the criteria is possible to produce.

- Auditors, preferably both from accredited organisations and actors aiming to be individual verifiers.

- The certification system operator learn from and document the trials.

- Researchers implementing the necessary changes to the systemif this is not part of the tasks assigned to the interim certification organisation.

- Representatives from the Nordic Council of Ministers to ensure that the aims of the commitment are fulfilled.

To make the trial certification attractive for actors aiming for certification, it should be designed in a way that makes a full certification easier and cheaper for the trial participants once the system is fully operational.

\subsection{Initial revision of criteria}

Experiences from the trial period should be used in a consultion with all stakeholders involved in the trials to suggest a first revision of certification criteria in the Voluntary commitment, certification system operation and code of conduct. The proposed changes should be made public with clear explanations to all interested parties why the changes are proposed with a period for external comments. 


\subsection{Fees}

After a trial period the proposed fees for certification should be adjusted to match both the needs for further development of the system and the needed administration of the certifications and communication of the system. The principle of a non-profit system shall apply to maximise the possibilities for organisations to commit to the system.

\subsection{Communication}

\subsubsection{Logotypes}

Logotypes for all actors involved in the system needs to be developed to ensure a clear communication of whether an actor is certified or not. It is also critical that developed logotypes cannot be mixed up with other systems and what the system ensures compliance with. Logotypes used during the development of the system needs to be revised to fit all purposes.

\subsubsection{Establishment of website}

The certifying organisation shall establish a website that serves stakeholders with relevant and updated information. This information includes:

- Up to date versions of the voluntary commitment, Code of conduct and certification system operation.

- The website shall also include a list of certified actor including the "be-noted"-list of unserious actors provided by the certifying organisation.

It may also include:

- Development and implementation of "best practice" guidelines and systems for collection, debranding, sorting, transport, reuse, recycling and waste treatment of used textiles and textile wastes (meant for actors in the market, both those which are certified and those which want to get certified or operate according to these criteria). 
- An on-line "best- practice"-library which is reported on a voluntary basis from the different Nordic countries (helps the exchange of best practice between countries and/or municipalities in order to "pick the best solutions").

The website information should be clearly divided into different areas depending on the receiver of the information such as consumers, municipalities and collectors.

\subsubsection{Spreading knowledge of the system}

The certifying organisation shall prepare common information campaigns. The information is further made available to the public through the operator of the certification system (via websites, annual reports etc.). National and local authorities can choose to supply with additional and more detailed information related to their geographical area. This is made available via the public information channels (websites, social media etc.).

\subsection{Evaluation}

After a period of three to five years, it is suggested that an independent evaluation is performed to ensure that the developed system fullfills the intended purpose and aim set by the Nordic waste group under the Nordic Council of Ministers.

The evaluation needs to be commissioned by the Nordic council of Ministers to ensure an independent evaluation. It should cover the impacts on all relevant actors including consumers. 


\section{Guidelines for Nordic textile commitment}

This section provides questions and answers to the Nordic textile commitment. It is to support and elaborate some of the issues in the documents "Voluntary commitment", "Code of conduct" and "Certification and System operation". The development of the Nordic textile commitment has demanded compromises and negotations between the views of different stakeholder which this section attempts to clarify.

Text from the voluntary commitment, code of conduct and certification and system operation documents is marked as italic. Criteria from the code of conduct are also marked with the identifying code (e.g. C2.2) to enable an easy connection to the criteria document.

\subsection{Voluntary commitment}

\subsubsection{General comments}

Many comments and questions during the development of the commitment relate to the municipal monopoly on household waste ${ }^{13}$ and how the commitment is affected and if/how public procurements will use the commitment. These issues have not been included in the project and will not have any clear answer at this time. For Sweden, these issues are being investigated by Waste Management Sweden.

From the standpoint of the commitment and code of conduct, section 4.5 states that "All signatories shall comply with local, regional, national and international laws and regulations. In the case of a conflict between the commitment and the law, the law has precedence and the system operator shall be informed of the deviation."

13 Which include textile waste, meaning textiles aimed for recycling or other waste treatment, but no including textiles aimed for reuse. See EU Directive 2008/98/EC article 3, §1 and §13. 
This means that where textile wastes are under the municipal waste monopoly it cannot be collected without an agreement with the municipality. However, it is strongly encouraged to collect textile and textile waste in a mixed fraction as part of such an agreement since it is deemed impossible for the consumer to make the distinction.

\subsubsection{Section specific comments}

\section{Aim and purpose}

The aim of the voluntary commitment is to engage stakeholders in commiting to common goals of reducing the environmental impact from textile consumption and increasing the competitiveness of the Nordic region:

- The system can be used outside of the Nordic region and add value also on other markets but the main aim is to enable a professional management in the Nordic region and thus providing a more competitive business.

Within ten years double the share of post-consumer clothing and home textiles that are collected separately across the Nordic region compared to 2012:

- Calculated as the share collected of the total textiles put on the market the same year.

Strive towards a ten year goal of at least $50 \%$ of collected textiles are reused (either in Nordic countries or abroad) and $90 \%$ of the total is reused or where reuse not possible, recycled. Aim towards closed loop recycling rather than downcycling:

- A level of 50\% might seem low considering that some actors reuse $70-80 \%$, but the level is set considering that collector shall accept all textiles that are reuseable or recyclable. The level can be adjusted by the certification committee (see certification and system operation) if needed.

- That it can be done both within the Nordic countries and abroad is to make it clear that export of textiles is a valid option. 
Audits shall be performed every three years and unscheduled audits on all or parts of the criteria can be performed at any time:

- A period of three years have been chosen as compromise between audit costs and complete control of the certification

\section{Commitment}

The common criteria include supporters that have signed the commitment.

Signatories shall have a social code of conduct following the principles of the $\mathrm{BSCl}^{14}$ principles or similar:

- Meaning equal to the requirements in the BSCI code of conduct, but not necessarily the other components of the BSCI.

Signatories putting new textiles on the Nordic market may, when possible, only cooperate with signatories in this commitment with regards to collection, sorting, reuse and recycling of textiles:

- It may not be possible e.g. for geographic reasons, if there are no certified collectors in the area of operation.

Municipalities shall, where possible, prioritise signatories when giving permits for collection on public land. They shall also take action against illegal collection:

- This is not always possible to do directly, but can also be done indirectly e.g. by meeting with law enforcement to convince law enforcement to prioritize acting on illegal collection.

Municipalities may perform collection, sorting, reuse and recycling in accordance with the code of conduct:

- Comments have been addressed that municipalities shall not engage in reuse. They likely have limited possibilities to compete in the second hand marked without violating competition regulation and this activity should therefore be limited by section 4.5. Municipalities are encouraged to cooperate with signatories within collection.

${ }^{14}$ Business Social Compliance Initiative. 


\subsection{Code of conduct}

It is aimed at any organisation performing collection, sorting, reuse and recycling of used textiles:

- It is primarily aimed at Nordic organisations and their partners but no need to limit the use of the criteria to Nordic actors have been identified.

- De-branding is included as reuse or recycling depending on the type of technique used.

Traceability of textiles shall be possible until end users being either private customers or recycled products. (C2.2):

- This criteria should be considered with some reason from the auditer since it will be difficult to follow textile being spread troughout the international market. The general rule shall be that textiles are tracable until no further sorting is made. For the final transactions of textile, sample checks may be sufficient.

All collected textiles shall be documented with weight or volume and source of origin. (C2.5):

- As an example, it should be clear that $X$ tonnes originates from collection containers in the municipality of $Y$ during year Z. If reported figures are questionable in any aspect, the auditor might request further information or perform a sample check for a number of containers.

Collectors shall accept all other textiles that are clean and non hazardous. This includes torn, worn-out and incomplete textiles (e.g. single socks). This should be made clear to the consumer. (C3.3):

- This does not include soiled or wet textiles, since they can contaminate other textiles.

- Hazardous can be either by REACH SVHC or national hazardous waste definitions or other. The criteria is openly defined on purpose to become more specific in future revisions 
The collector shall specify which day collection will take place. (C3.5):

- This critera may seem too detailed but relates to the risk of littering due to bags being left out for days, the risk of contaminating textiles for the same reason and for multi-storey buildings for fire safety reasons not to have bags ultimately blocking escape routes.

Information on which products are accepted in the collection shall be clearly stated to the consumer. (C3.7):

- C3.3 should of course be fulfilled, but collection together with other products not contaminating the textile (e.g. toys) may also be done.

Sorting performance shall be given for a specific supplier or as the residual of received material not included in sorting performance for a specific supplier. (C4.6):

- Sorting performance according to C4.2-4.5 can be given to a textile supplier either as specific to their textiles (if available) or as the average fractions of the sorting not specified for any specific supplier. If specific sorting performance is not provided to anyone, the sorting performance will be the average for all textile sorting performed during the specific year.

Recyclers shall report the level of recycling in percentage weight or volume of received textiles and the distribution between recycled products. (C5.1):

- Volume might not be specific enough and this might need to be changed in future revisions.

The percentage of sold (or donated) used textiles as a share of received used textiles together with the fate of unsold textiles shall be reported. Only the sold or donated (actually reused by a final user) textiles may be included as reused. (C6.2):

- If sales are made to a middle man, their average reuse rate can be used to calculate the percentage reused textiles. 
Collected used textiles shall only be sold to companies with the requested competence regarding handling of these material flows. (C7.1):

- Certificates or similar is a clear way of fulfilling the requirement.

At least $50 \%$ of collected textiles shall be reused (annually) either by charity reuse, domestic sales or by export to an organization guaranteeing the level of reuse. (C8.2):

- This criteria can be impossible for some actors, e.g. laundries, hotels and similar and there is need for further development of the criteria to allow for these actors to be part of the system. Since these actors relation to private consumers are more limited than the collection of other used textiles and textile waste, this was not prioritized at this time. Donations for reuse e.g. to aid organisations can be a tool to increase reuse levels.

- A guarantee of reuse should of course be documented with how the level of reuse can be guaranteed.

- A level of $50 \%$ might seem low considering that some actors reuse $70-80 \%$, but the level is set considering that collector shall accept all textiles that are reuseable or recyclable. The level can be adjusted by the certification committee if needed.

At least $90 \%$ of collected textiles shall either be reused or used as input for recycling (annually). The recycling should have a material efficiency of at least $60 \%$. Recycling of textiles not suitable for reuse shall be according to best available technique with priority given to closed loop recycling before low grade recycling. (C8.3):

- Additional requirements on disposal of residues from sorting and recycling might be needed. This could for example be critera that nothing should be landfilled, and that incineration should have both energy recovery and sufficient flue gas treatment.

- A material efficiency of at least $60 \%$ means that at least $60 \%$ of the input material shall be part of the products containing recycled material.

- A list of best available technique should be created following the implementation of the system. 
Collected items that are not textiles should not be included in the calculation regardless of being waste or other products with the exception of shoes. If shoes are included, this should be clearly stated. (C8.5):

- Note that bags and similar items made of textiles are to be included.

All signatories shall in all stages of the textile life cycle actively work towards an efficient management of textiles. This includes transports, facilities and all other activites related to the collection, sales/reuse, sorting and recycling of textiles. (C8.6):

- This criterion is similar to ISO14001 criteria and addresses the process of continuous environmental improvement.

All signatories shall work towards the removal of textiles containing hazardous or otherwise unwanted chemicals. (C8.7):

- This should of course be done with help from governments and together with producers and other organisations. The criteria is openly defined on purpose to become more specific in future revisions.

- "Unwanted chemicals" is a phrase to include chemicals that may be hazardous in some way, but which at present are not formally recognised as hazardous.

A socially benefitial actor shall (for at least six of the following criteria): (C9.1):

- The criteria are to some extent not clearly defined and a practice will evolve over time to better form what is approved and not approved.

- Comments that a certified charity status should be required have been given. This has been investigated and it is very difficult to define on a Nordic level. As an example, the Swedish 90-account only specifies how money raised is used, while the chosen criteria give a broader definition.

- One single criteria does not necessarily signify a socially benefitial actor, but the combination of a least 6 criteria together does. 


\subsection{Certification and system operation}

\section{Enforce sanctions for malpractice or illegal activities}

- Enforcement might for example be putting the relevant actors on a be-noted list or giving public warnings of certain actors.

\section{Role and function of certification committee}

- The final composition of the certification committee is to be determined. The members should primarily be chosen by their respective sector to give a voice not only for themselves. The committee assist the certification system operator. An interim committee are suggested to be put together for the start up of the system.

Certification can be done either by accredited certification bodies or by individual verifiers.

The use of individual verifiers is to make the certification cheaper and more flexible.

\section{General knowledge of the entire textile industry}

- This criteria is broadly defined and used to ensure that the verifier has some general experience of the textiles industry and thereby will be more difficult to mislead by the organisation being certified.

\section{Individual verifiers}

- The use of individual verifiers is to make the certification cheaper and more flexible. There might be an increased risk of bias and corruption, but the verifiers will be controlled by the certification system operator and the certification committee. Other systems such as the International EPD-system have used individual verifiers successfully for many years.

\section{The certification process}

Since it is not uncommon to have an umbrella organisation with multiple legal entities, it will be possible to certify the umbrella organisation and thus include all entities in one certificate. This of course given that all connected entities as a whole fulfils the criteria.

Performance of all downstream actors shall be documented and available to the auditer:

- This criteria should be considered with some reason from the auditer since it will be difficult to follow textile being spread troughout the 
international market. The general rule shall be that textiles are tracable until no further sorting is made. For the final transactions of textile, control samples may be sufficient.

If significant changes to the signatory operation are made during this period a supplementary certification shall be performed. If there is any uncertainty to whether a change constitutes a significant change, the certification system operator shall be notified:

- If customers/partners change, this is a change that should be reported. If a contract with a customer/partner is renewed without changes, this does not need to be reported.

\section{Irregularity reports and sample checks}

- An additional fee may be needed for extra site visits if irregularities are found.

\section{Logotypes}

- Logotypes are not finalized and may be further developed by an interim certification organisation during implementation of the system.

\section{Fees}

- Fees are only very preliminary and will depend on who will be the system operator and the number of certified actors. They have been calculated as rough estimates based on similar systems (e.g. the international EPD-system) and a reasonable number of certified organisations. The principle is that the certification organisation shall be self-financed and non-profit.

Municipalities might have administrative and legal issues with paying fees to the system. To ensure a high level of commitment on the important practical cooperation with certified actors, they have been exempt from fees. 



\section{References}

Innsamlingskontrollen. 2014. http://www.innsamlingskontrollen.no Accessed 2014-09-24

Hansen et al. 2014. Report on Food banks in preparation. Østfoldforskning.

Svensk Insamlingskontroll. 2014. http://svenskinsamlingskontroll.se/ Accessed 2014-09-24 



\section{Sammanfattning av rapporterna}

Denna rapport ger en fullständig dokumentation av det frivilliga åtagandet för ökad återanvändning och återvinning av textilier i Norden. Den innehåller ett dokument som beskriver ett frivilligt åtagande och fyra stödjande dokument.

Dokumenten är:

- Frivilligt åtagande.

- Uppförandekod för hantering av begagnade textilier.

- Certifiering och drift av systemet.

- Vägledning och implementering.

- Förteckning över aktörer som stödjer det frivilliga åtagandet.

Rapporten ingår i de nordiska statsministrarnas initiativ för grön tillväxt: "Norden - ledande i grön tillväxt" - läs mer i webbtidningen "Green Growth the Nordic Way" på adressen www.nordicway.org eller www.norden.org/sv/tema/green-growth

\section{Frivilligt åtagande}

Detta dokument beskriver ramverket för ett frivilligt åtagande mellan aktörer i textilsektorn och myndigheter i de Nordiska länderna. Det inkluderar åtaganden inom miljö, socialt ansvar, kommunikation, samarbete och efterlevnad av lagar samt särskilda åtaganden för aktörer i de olika delarna av återanvändning och återvinning av textilier. Textilier som ingår är kläder och hemtextil.

Det frivilliga åtagandet består av förhandlade mål för industrin samt särskilda åtaganden för de olika aktörerna i textilsektorn. Åtagandet är inte ett frivilligt system för producentansvar och ersätter inte andra åtgärder för en mer hållbar hantering av textilier i Norden.

Syftet med det frivilliga åtagande är att engagera aktörer att sträva mot gemensamma mål för att minska miljöpåverkan från textilkonsumtion och samtidigt öka Nordens konkurrenskraft. Det tillhandahåller ett tredjeparts-certifierat system för seriös och hållbar insamling, sortering, återanvändning och återvinning av textilier från de deltagande aktörerna. Undertecknarna är ansvariga för kriterier inom sitt område. 
Målen för åtagandet är att:

- Möjliggöra för seriösa aktörer att samla in, sortera, återanvända och återvinna textilier i samarbete med producenter, importörer och myndigheter.

- Eliminera olaglig insamling, export och handel med begagnade textilier.

- Öka insynen i vad som händer med insamlade textilier och syftet med insamlingen och öka allmänhetens förtroende för att insamlingsorganisationer.

- Inom tio år fördubbla andelen begagnade textilier som samlas in separat i Norden jämfört med 2012.

- Sträva mot att inom tio år nå en nivå där minst $50 \%$ av insamlade textilier återanvänds (antingen i Norden eller i utlandet) och $90 \%$ av den totala insamlade mängden återanvänds eller återvinns där återanvändning inte är möjligt. Arbeta mot cirkulär återvinning snarare än downcycling.

- Säkerställa att alla aktörer följer tredjepartsverifierade sociala och etiska regler.

\section{Uppförandekod för hantering av begagnade textilier}

Detta dokument beskriver specifika kriterier i samband med insamling, sortering, återanvändning och återvinning av begagnade textilier. Det riktar sig till alla organisationer som utför insamling, sortering, återanvändning och återvinning av begagnade textilier, oavsett välgörenhetsstatus eller inte.

Kriterier ges för insamling i allmänhet och speciellt för i butiksinsamling, fastighetsnära insamling och containersamling. Kriterier ges också för sortering, återvinning, återanvändning och försäljning av återanvända textilier och export av begagnade textilier samt miljöprestanda, transparens och rapportering. Kriterierna är uppdelade i bör och skall, där bör är visionära kriterier och skall måste uppfyllas och vara dokumenterade.

För aktörer som hävdar status som socialt fördelaktig aktör finns en lista på tio kriterier av vilka sex måste uppfyllas. Detta möjliggör för "välgörenhetsorganisationer" i en bred definition att visa konsumenterna att de tillhandahåller något extra för samhället utöver hållbar textilhantering samtidigt som kommersiella aktörer med enbart miljönytta kan vara en del av certifieringssystemet. 


\section{Certifiering och drift av systemet}

Detta dokument beskriver praktiska delar kring drift av certifieringssystemet runt det frivilliga åtagandet och uppförandekoden. Det ger information om systemets funktion, certifieringsorganisationer, certifieringsprocessen och framtida utveckling av certifieringssystemet.

Certifieringsoperatörens roll beskrivs tillsammans med en stödjande certifieringskommitté. Certifieringsoperatören är den organisation som driver certifieringssystemet i alla praktiska aspekter med att utse ackrediterade certifierare, utveckling av systemet, information och register över certifierade aktörer samt avgifter. Certifieringsoperatören utför inte certifieringsrevisioner, utan godkänner organisationer och individer som gör detta baserat på fördefinierade kriterier. Certifieringskommittén består av representanter för de olika aktörer som berörs av systemet och hjälper certifieringsoperatören i utvecklingen av systemet. Den ser till att systemet kan anpassas till ändrade förhållanden och har en fortsatt relevans för återanvändning och återvinning av textilier.

Dokumentet beskriver även certifieringsprocessen med erforderlig dokumentation, giltighetstid och kontroll av certifiering. Certifieringsavgifter för olika aktörer och villkoren för avgifter beskrivs också här. Slutligen återfinns även preliminära logotyper och villkoren för användning av dessa här.

\section{Vägledning och implementering}

Det föreslagna systemet kräver en testperiod där de föreslagna kriterierna kan testas för att hitta eventuella kryphål eller andra frågor som måste lösas innan en fullständig implementering av systemet. Detta dokument ger vägledning för en testperiod och uppstart av det föreslagna systemet. Det ger en grundläggande struktur för försöksperioden och efterföljande revideringar av kriterierna.

Det var inte under projektets gång möjligt att hitta en certifieringsoperatör redo att ta över det föreslagna systemet. En kort beskrivning av viktiga faktorer för en certifieringsoperatör och de undersökta organisationerna ges också här för att underlätta det framtida arbetet med att lokalisera och utse en operatör.

Utvecklingen av det frivilliga åtagandet har inkluderat förhandlingar om kriterier för att hitta en nivå där hanteringen av begagnade textilier flyttas mot förbättrad hållbarhet samtidigt som det ska vara möjligt att uppnå. De slutliga formuleringarna i det frivilliga åtagandet, uppföran- 
dekoden och certifiering och drift av systemet har noga valts ut och kan vara svårt för aktörer som inte deltagit i utvecklingsprocessen att förstå. Det här dokumentet ger därför riktlinjer för alla dokument med mer utförliga beskrivningar av flera av kriterierna. Dessa riktlinjer är baserade på frågor som getts under utvecklingsprocessen.

\section{Förteckning över aktörer som stödjer det frivilliga åtagandet}

Den sista delen av rapporten är en lista över aktörer som aktivt har valt att visa sitt stöd för den framtida utvecklingen och implementeringen av det frivilliga åtagandet och certifieringssystemet. Listan omfattar producenter, kommuner, välgörenhetsorganisationer, kommersiella insamlare med flera från hela Norden. 


\section{Actors supporting the Voluntary Commitment}

The following organisations are committed to supporting the trials and implementation of the Voluntary Commitment and the Code of Conduct. They will support the future work through e.g. participation in reference group and/or certification trials of the proposed system. ${ }^{15}$

- Myrorna, Sweden.

- Swedish Red Cross, Sweden.

- UFF Denmark.

- Human Bridge, Sweden.

- TextilRecycling, Sweden.

- Kirkens Korshaer, Denmark.

- Trasborg, Denmark.

- City of Göteborg, Sweden.

- City of Stockholm, Sweden.

- Mepex, Norway.

- City of Malmö, Sweden.

- UFF Finland. 
Nordic Council of Ministers

Ved Stranden 18

DK-1061 Copenhagen K

www.norden.org

\section{The Nordic textile commitment}

\section{The Nordic textile commitment}

A proposal of a common quality requirement system for textile collection, sorting, reuse and recycling

The Nordic textile reuse and recycling commitment aims to engage stakeholders in committing to common goals of reducing the environmental impact from textile consumption and increasing the competitiveness of the Nordic region. It provides a third party certified system for legitimate sustainable collection, sorting, reuse and recycling of textiles. The report covers the main principles of a commitment.

The report is part of the Nordic Prime Ministers' overall green growth initiative: "The Nordic Region - leading in green growth" - read more in the web magazine "Green Growth the Nordic Way" at www.nordicway.org or at www.norden.org/ greengrowth

TemaNord 2015:512

ISBN 978-92-893-3965-0 (PRINT) ISBN 978-92-893-3967-4 (PDF) ISBN 978-92-893-3966-7 (EPUB) ISSN 0908-6692

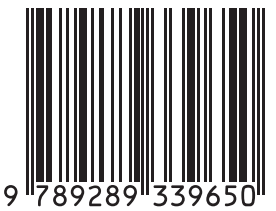

